\title{
Gambaran Karakteristik, Pengetahuan, Dan Sikap Petani Pengguna Pestisida Di Kecamatan Pasirian Kabupaten Lumajang
}

\section{Description Of Characteristics, Knowledge, And Attitudes Of Pesticides User Farmers In Pasirian Sub- District, Lumajang District}

\author{
Fitri Dika Maharani ${ }^{1}$, Erma Sulistyaningsih ${ }^{2}$ (CA), Hadi Prayitno ${ }^{3}$ \\ ${ }^{1}$ Program Pascasarjana Kesehatan Masyarakat, Universitas Jember, Indonesia; \\ ${ }^{2}$ (CA)Fakultas Kedokteran< Universitas Jember, Indonesia \\ ${ }^{3}$ Fakultas Ilmu Sosial dan Politik, Universitas Jember, Indonesia \\ Email: sulistyaningsih.fk@unej.ac.id; fitridikamaharani94@gmail.com
}

\begin{abstract}
ABSTRAK. Penggunaan pestisida yang tidak sesuai dapat mengakibatkan masalah kesehatan jangka pendek atau jangka panjang yang serius. Proses pestisida masuk ke dalam tubuh adalah melalui kulit, respirasi, mulut, dan selaput lendir. Penggunaan alat pelindung diri (APD) merupakan upaya utnuk menjaga keamanan dan kesealmatan petani dalam penggunaan pestisida. Penelitian ini memiliki tujuan untuk mengetahui gambaran karakteristik, pengetahuan, sikap dan hubunganganny dengan pemakaian APD di Kecamatan Pasirian Kabupaten Lumajang. Jenis penelitian ini analisis deskriptif yang menggunakan pendekatan kuantitatif cross-sectional. Besarnya sampel yang digunakan sebanyak 100 petani yang dipilih dengan kriteria yang telah ditentukan. Pengumpalan data menggunakan kuesioner. Analisis data menggunakan univariat dengan distribusi frekuensi dan bivariat dengan Spearman rank test. Hasil penelitian menunjukkan bahwa sebagian besar (39\%) petani berusia 32-43 tahun, $39 \%$ berpendidikan tidak lulus SD, dan 47\% mempunyai pengalaman sebagai petani selama 5 tahun. Sebagian besar (50\%) petani mempunyai pengetahuan yang baik tentang pestisida dan $62 \%$ mempunyai sikap yang cukup terkait penggunaan pestisida. Pengetahuan dan sikap berhubungan dengan pemakaian APD dengan tingkat korelasi rendah dan sedang.
\end{abstract}

Kata kunci: pengetahuan, pestisida, petani, sikap

ABSTRACT. Improper use of pesticides can cause serious short-term or long-term health problems. The process of pesticides into the body is through the skin, respiration, mouth, and mucous membranes. The use of personal protective equipment (PPE) is an effort to maintain the safety and health of farmers in using pesticides. This study aims to describe the characteristics, knowledge, attitudes and relationships with the use of PPE in Pasirian District, Lumajang Regency. This type of research is a descriptive analysis using a cross-sectional quantitative approach. The sample size used was 100 farmers who were selected with predetermined criteria. Collecting data using a questionnaire. Data analysis used univariate with frequency distribution and bivariate with Spearman rank test. The results showed that most of the farmers (39\%) aged 32-43 years, 39\% had no primary school education, and $47 \%$ had experience as farmers for 5 years. Most of the farmers (50\%) have good knowledge about pesticides and $62 \%$ have sufficient attitudes regarding the use of pesticides. Knowledge and attitudes related to the use of PPE with low and moderate levels of correlation.

Key words: attitude, farmers, knowledge, pesticides.

\section{Pendahuluan}

Pestisida merupakan biosida artinya bersifat racun kepada tumbuhan dan juga manusia. Pemakaian pestisida yang tidak sesuai dapat mengakibatkan masalah kesehatan jangka pendek atau jangka panjang yang serius. Proses pestisida masuk ke dalam tubuh adalah melalui kulit, respirasi, mulut, dan selaput lender. Di negara-negara tropis di mana suhu dan kelembaban tinggi, serapan pestisida cenderung lebih tinggi karena suhu tubuh panas dan berkeringat (Jeyeratnam, 2009).

Organisasi dunia seperti WHO (World Health Organization) memprediksi kasus keracunan setiap tahun mencapai 1-5 juta kasus pada petani dengan tingkat kematian mencapai 220.000 jiwa. Prevalensi keracunan ini cenderung terjadi di Negara berkembang seperti Indonesia. Mengacu pada hasil penelitian Rahman et al (2014) menunjukkan bahwa sekitar $85 \%$ pekerja pertanian melaporkan menderita gangguan pencernaan selama dan setelah penyemprotan, sedangkan $61 \%$, 63\%, dan 47\% dari mereka melaporkan, masingmasing, ketidaknyamanan kulit, masalah mata, dan perasaan kelemahan. Berdasarkan data Sentra Informasi Keracunan Nasional (Sikernas) Jawa Timur pada tahun 2015 telah terjadi keracunan 29 orang disebabkan karena penggunaan APD yang tidak baik dan terpapar dengan cara terhirup.Data dari beberapa Puskesmas di Lumajang menunjukkan bahwa Puskesmas Pasirian menangani kasus 
keracunan pestisida paling tinggi dari puskesmas lainnya di Kabupaten Lumajang yaitu sebanyak 14 kasus. Keracunan disebabkan karena paparan terhirup sebab tidak menggunakan masker, dan sarung tangan.

Pemakaian pestisida yang salah dan tidak aman bisa menjadi ancaman bagi kesehatan manusia, karena mereka kontak langsung dengan pestisida. Petani berisiko terpapar pestisida melalui persiapan, penanganan, pencampuran, penyemprotan. Oleh karena itu, keracunan pestisida merupakan risiko pekerjaan yang penting di kalangan petani. Untuk meminimalkan paparan dan akibatnya pada kesehatan selama fase aplikasi. Pemakaian Alat Pelindung Diri (APD) tertentu: baju kerja, sarung tangan, kacamata, dan sepatu bot. Sayangnya, sering terjadi bahwa petani kecil di negara berkembang gagal mematuhi standar keselamatan ini. APD sangat dibutuhkan dan berperan penting terhadap keselamatan dan keamanan petani dari risiko keracunaan dari penggunaan pestisida. Menurut Occupational Safety and Health Administration (OSHA) menjelaskan jika APD adalah peralatan yang digunkan untuk melindungi diri dari kecelakaan kerja seperti keracunan yang disebabkan adanya kontak dnegan pestisida. Kabupaten Lumajang merupakan salah satu daerah pertanian bahkan lumbung pangan Jawa Timur. Sektor pertanian padi memiliki potensi sebagai komoditas andalannya. Mengacu pada sensus pertanian tahun 2013 menunjukkkan jika sebanyak 168.127 pertanian dikelola oleh rumah tangga dan sebanyak 17 dikeloloa oleh perusahaan pertanian berbadan hokum dan sebanyak 3 dikelola oleh selain rumah tangga dan perusahaan tidak berbadan hokum (NRT). Sampai saat ini pengelolaan pertanian belum menerapkan standar keselamatan dan keamanan pemakaian pestisida. Berdasarkan pada data yang diperoleh dari UPT Pertanian di Kabupaten Lumajang menunjukkan bahwa populasi petani paling banyak berada di Kecamatan Pasirian Kabupaten Lumajang. Hasil studi awal yang dilakukan pada petani pada saat pemakaian pestisida didapati beberapa permasalahan yang dapat mengancam kesehatan, seperti tidak menggunakan pestisida sesuai dengan standart seperti pemakaian masker yang masih jauh dari kata aman dari bahaya keracunan. Petani di Kecamatan Lumajang sebagian besar dalam pemakaian pestisida tidak menggunakan pengaman pada umumnya, masker yang digunakan terkadang hanya dari baju bekas dan menggunakan topi, sehingga gas dari pestisida akan dengan mudah masuk pada pernapasan atau alat indera seperti mata. Pada tahun 2018-2019 dilakukan kolinesterase bahwa di kecamatan Pasirian terdapat petani yang keracunan pestisida terbanyak di kabupaten lumajang sebesar 15 petani. Penelitian inibertujuanuntuk mengetahui gambaran karakteristik, pengetahuan, dan sikap petani pengguna pestisida di Kecamatan Pasirian Kabupaten Lumajang.

\section{Bahan dan Metode}

Desain penelitian ini adalah studi crosssectionaldenganpopulasipetani padi di Kecamatan Pasirian berjumlah 22.751 orang. Sampel dalam penelitian ini 100 petani yang dipilih dengan teknik proporsional random sampling. Penelitian ini telah mendapatkan ijin etik dari Komisi Etik Penelitian Fakultas Kedokteran Gigi Universitas Jember. Pengumpulan data menggunakan kuesioner yang telah diuji validitas dan reliabilitasnya. Analisis datam enggunakan univariat dengan distribusi frekuensidan bivariat dengan Spearman rank test.

\section{Hasil dan Pembahasan}

Tabel 1. Deskripsi responden berdasarkan karakteristiknya

\begin{tabular}{llll}
\hline No & Karakteristik & Frekuensi & $\%$ \\
\hline 1. & Usia & & \\
\hline & 18-31 Tahun & 35 & 35.0 \\
& 32-43 Tahun & 39 & 39.0 \\
& 44-55 Tahun & 26 & 26.0 \\
\hline 2. & Pendidikan & & 39.0 \\
\hline & Tidak lulus SD & 39 & 24.0 \\
& Lulus SD & 24 & 26.0 \\
& Lulus SMP & 26 & 11.0 \\
\hline Lulus SMA & 11 & 100 \\
\hline Pengalaman & 100 & 22.0 \\
\hline & <5 tahun & 22 & 47.0 \\
& 5 tahun & 47 & 31.0 \\
\hline >5 tahun & 31 &
\end{tabular}

Berdasarkan pada tabel 1 dapat diketahui bahwa umur petani paling rendah berusia 18 tahun dan paling tinggi adalah 55 tahun. Sebagai besar petani berada pada kelompok usia 32-43 tahun.Gambaran pendidikan sebagian besar petani adalah tidak lulus SD (39\%). Sedangkan pengalaman kerja petani paling rendah adalah 1 tahun dan paling tinggi adalah 15 tahun. Sebagain besar petani telah berpengalaman selama 5 tahun.

Gambaranpengetahuan petani tentang pestisida dapat dilihat pada tabel 2 . sebagian besar memimiliki pengetahuan yang baik terhadap pestisida sebanyak 50 atau $50 \%$.

Tabel 2 Tingkat Pengetahuan Petani Padi terhadap Pestisida di Kecamatan Pasirian Kabupaten Lumajang

\begin{tabular}{llll}
\hline No & Pengetahuan & Frekuensi & Persentase $(\%)$ \\
\hline 1 & Baik & 50 & 50.0 \\
2 & Cukup & 29 & 29.0 \\
3 & Kurang & 21 & 21.0 \\
\hline & Total & 100 & 100
\end{tabular}

Gambaran sikap petani tentang pestisida dapat dilihat pada table 3. sikap petani padi sebagian besar adalah cukup terhadap terhadap pestisida sebanyak 62 atau $62 \%$. 
Tabel 3 Tingkat Sikap Petani Padi terhadap Pestisida di Kecamatan Pasirian Kabupaten Lumajang

\begin{tabular}{llll}
\hline No & Sikap & Frekuensi & $\begin{array}{l}\text { Persentase } \\
(\%)\end{array}$ \\
\hline 1 & Baik & 13 & 13.0 \\
2 & Cukup & 62 & 62.0 \\
3 & Kurang & 25 & 25.0 \\
\hline & Total & 100 & 100 \\
\hline
\end{tabular}

dibuktikan dengan nilai $\mathrm{P}$ value $0.000 \leq 0.05$, dengan kekuatan hubungan berada pada kategori sedang.

Tabel 6. Tabel hasil uji Rank Spearman
Gambaran pengetahuan petani yang ditabulasi silang dengan pemakaian APD dapat dilihat pada table 4, sedangkan hasil tabulasi silang antara sikap petani tentang pestisida dengan pemakain APD dapat dilihat pada table 5 .

Tabel 4 Tabulasi Silang Pengetahuan dengan Pemakaian APD petani di Kecamatan Pasirian

\begin{tabular}{lll}
\hline \multirow{2}{*}{$\begin{array}{l}\text { Pengetahuan } \\
\text { Pestisida }\end{array}$} & tentang & \multicolumn{2}{c}{ Penggunaan APD } \\
\cline { 3 - 3 } & Baik & Cukup \\
\hline Baik & 10 & 24 \\
Cukup & $20.00 \%$ & $48.00 \%$ \\
& 0 & 6 \\
Kurang & $0.00 \%$ & $20.70 \%$ \\
& 0 & 8 \\
Total & $0.00 \%$ & $38.10 \%$ \\
& 10 & 38 \\
\hline
\end{tabular}

Berdasarkan table 4 dapat diketahui bahwa petani dengan pengetahuan baik mayoritas cukup dalam pemakaian APD. Petani dengan tingkat pengetahuan cukup mayoritas kurang dalam pemakaian APD. Sedangkan petani dengan tingkat pengetahuan kurang sebagian besar kurang dalam pemakaian APD.

Tabel 5 Tabulasi Silang Sikap dengan Pemakaian APD petani di Kecamatan Pasirian Kabupaten Lumajang

\begin{tabular}{lll}
\multirow{2}{*}{ Sikap } & \multicolumn{2}{l}{ Penggunaan APD } \\
\cline { 2 - 3 } Baik & 5 & Cukup \\
\multirow{3}{*}{ Cukup } & $38.50 \%$ & 7 \\
& 5 & $53.80 \%$ \\
Kurang & $8.10 \%$ & $48.40 \%$ \\
& 0 & 1 \\
Total & $0.00 \%$ & $4.00 \%$ \\
& 10 & 38 \\
& $10.00 \%$ & $38.00 \%$ \\
\hline
\end{tabular}

Tabel 5menunjukkan bahwa mayoritas petani dengan sikap baik akan cukup dalam pemakaian APD,petani dengan sikap cukup juga cukup dalam pemakaian APD. Sedangkan sebagian besar petani dengan sikap kurang juga kurang dalam pemakaian APD.

Hasil analisis data dengan uji Spearman Rank ditunjukkan dalam table 6.Tingkat pengetahuan berhubungan dengan pemakaian APD dibuktikan dengan nilai $\mathrm{P}$ value $0.000 \leq$ 0.05 , dengan kekuatan hubungan berada pada kategori rendah. Sikap berhubungan dengan pemakaian APD

\begin{tabular}{llllll} 
Variabel & $\mathrm{P}$ & $\alpha(0,05)$ & Hipotesis & $\begin{array}{l}\text { Koefisien } \\
\text { Korelasi }\end{array}$ & $\begin{array}{l}\text { Tingkat } \\
\text { Hubungan }\end{array}$ \\
\hline $\begin{array}{l}\text { Vingkat } \\
\text { pengetahuan }\end{array}$ & 0.000 & $\leq 0.05$ & Diterima & 0.381 & Rendah \\
$\begin{array}{l}\text { Sikap } \\
\text { Sika }\end{array}$ & 0.000 & $\leq 0.05$ & Diterima & 0577 & Sedang
\end{tabular}

Pestisida banyak digunakan oleh petani dalam rangka membasmi hama dan meningkatkan produksi pertanian. Tetapi penggunaan pestisida yang tidak sesuai dapat mengakibatkan masalah lingkungan dan gangguan masalah kesehatan pada manusia baik melalui paparan akut maupun kronis. Dalam penelitian ini dilakukan analisis karakteristik petani di Kecamatan Pasirian Kabupaten Lumajang serta pengetahuan dan sikapnya terkait dengan pestisida dan penggunaannya.

Berdasarkan pada tabel 1 yang menunjukkan karakteristik petani, dapat diketahui bahwa umur petani paling rendah berusia 18 tahun dan paling tinggi adalah 55 tahun. Sebagai besar petani berada pada kelompok usia 32-43 tahun. Usia berkaitan dnegan kemampuan fisik seseorang dalam bekerja. Berdasarkan pada pendidikan sebagian besar petani adalah tidak lulus SD mencapai 39\%. Pendidikan berkaitan dengan informasi yang dimilikinya. Sementara pengalaman kerja petani berada pada rentang 1 - 15 tahun dansebagian besar pengalaman sebagai petani sebanyak 5 tahun. Pengalaman berkaitan dengan kemampuan dan keterampilan dalam pemakaian pestisida.

Berdasarkan pada hasil penelitian menunjukkan jika pengetahuan memiliki hubungan dengan pemakian APD dengan nilai statistic sebesar $0.000<0.05$ dengan kekuatan hubungan berada pada kategori rendah. Hasil penelitian ini sesuai dengan teori yang disampaikan oleh Lawrence Green yang dikutip oleh Notoadmodjo (2012) yang menjelaskan pengetahuan merupakan factor predisposisi yang membentuk perilaku manusia, sehingga baik buruknya pengetahuan akan berdampak paa baik atau tidaknya perilaku seseorang. Begitu pula dengan penggunaan APD. Lebih lanjut Notoadmodjo (2012) menjelaskan bahwa proses memperoleh pengetahuan seseorang sangat beragam bisa dari pendidikan formal maupun informal, penyuluhan media social dan lai sebagainya. Hasil penelitian ini didukung dengan penelitian yang dilakukan oleh Prasetyo (2015) yang menunjukkan hasil yang relevan yaitu keterkaitan antara sikap dengan kepatuahn dalam menggunakan APD. Penelitian Ruhyandi dan Evi(2008) memberikan hasil bahwa perilaku kepatuha penggunaan APD sangat berhubungan dengan pengetahuan yang dimilikinya. Penelitian ini serupa dengan hasil penelitian yang dilakukan oleh Elfrida (2006) yang memberikan hasil bahwa perilaku kepatuhan penggunaan APD sangat berhubungan dengan pengetahuan yang dimilikinya.

Hasil penelitian ini menunjukkan bahwa sikap berhubungan dengan pemakaian APD dibuktikan secara ststaistik dengan 
nilai $0.000<0.05$ dengan kekuatan hubungan berada pada kategori sedang. Hasil penelitian ini sesuai dengan pendapat Notoatmodjo (2012) bahwa sikap seseorang yang baik terhadap suatu nilai tidak selalu terwujud dalam suatu tindakan nyata, karena sikap akan terwujud dalam bentuk tindakan tergantung dari situasi tertentu. Menurut Soeripto (2009) memberikan pemahman bahwa sikap merupakan kesadaran dan kecenderungan seseorang dalam berbuat. Hasil penelitian ini didukung dengan penelitian yang dilakukan oleh Wismaningsih dan Dianti (2015) yang menunjukkan bahwa penggunaan APD sangat berhubungan dengan siakap. Repi dkk (2016) melaporkan bahwa 50\% responen memiliki sikap positif.

Sikap berhubungan dengan tindakan pemakaian APD. Prasetyo(2015) menunjukkan hasil yang relevan yaitu keterkaitan antara sikap dengan kepatuahn dalam menggunakan APD. Ruhyandi dan Evi (2008) memberikan hasil yang cukup relevan yaitu keterkaitan antara sikap dengan perilaku kepautahan pemakaian APD. Hasil penelitian berbeda dilakukan oleh Ahmad (2012), yang melaporkan bahwa sikap dengan praktik pemakaian APD tidak berkaitan, sehingga pemakian APD yang lengkap disebabkan oleh factor lain.

\section{Kesimpulan}

Hasil penelitian menunjukkan bahwa sebagai besar petani berada pada kelompok usia 32-43 tahun. Gambaran pendidikan sebagian besar petani adalah tidak lulus SD (39\%). Sebagain besar petani telah berpengalaman selama 5 tahun. Terdapat hubungan dengan tingkat rendah dan sedang pengetahuan dan sikap antara sebagaipredisposing factors dengan pemakaian APD pada petani padi di Kecamatan Pasirian Kabupaten Lumajang. Perlunya upaya bimbinganpenyuluhan, dan pengawasan secara intens pada petani mengenai K3 terutama berkaitan dengan pemakaian pestisida, untuk meningkatkan kesadaran petani dengan pemakaian APD terhadap dampak yang berpotensi ditimbulkan, yang melibatkan beberapa pihak seperti Dinas Pertanian, Dinas Kesehatan serta akademisi.

\section{Referensi}

1. Alamsyah, Dedi., R. Muliawati. 2013. Pilar Dasar Ilmu Kesehatan Masyarakat. Yogyakarta: Nuha Medika

2. Elfrida, N. 2006. Faktor-Faktor Yang Berhubungan Dengan Penggunaan APpada Pekerja di Bagian Produksi Packing PT. KCI (Industri Konsolidasi Kangan). Skripsi. Jakarta: FKM UI.

3. Jeyaratnam, J dan David Koh. 2009. Buku Ajar Praktik Kedokteran Kerja. Jakarta: Penerbit Buku Kedokteran EGC.

4. Prasetyo, 2015. Pengaruh Pengetahuan, Sikap, dan mode Alat Pelindung Diri (APD) Terhadap Kepatuhan dalam Menggunakan APD di Unit Coating PT. Pura Barutama Kudus. Cendekia Utama, Jurnal keperawatan dan kesehatan masyarakat. Vol 2, No.3 Maret 2015. Stikes Cendekia Utama Kudus

5. Repi dkk. 2016. Hubungan Antara Pengetahuan Dan Sikap Dengan Tindakan Penggunaan Alat Pelindung Diri Pada Tenaga Kerja Di Pt Tropica Cocoprima Desa Lelema Kecamatan Tumpaan Kabupaten Minahasa Selatan. Fakultas Kesehatan Masyarakat Universitas Sam Ratulangi. 